\title{
Parasites of the Southern silvery grebe Podiceps occipitalis (Aves, Podicipedidae) in Chile
}

\author{
Parasitas do mergulhão-de-orelha-amarela Podiceps occipitalis (Aves, Podicipedidae) no Chile \\ Daniel González-Acuña ${ }^{1}$; Sebastián Llanos-Soto ${ }^{2}$; Carlos Landaeta-Aqueveque ${ }^{1}$; Felipe González; \\ John Mike Kinsella ${ }^{3}$; Sergey Mironov ${ }^{4}$; Armando Cicchino ${ }^{5}$; Carlos Barrientos ${ }^{6}$; Gonzalo Torres-Fuentes ${ }^{1}$; \\ Lucila Moreno ${ }^{2 *}$
}

\author{
${ }^{1}$ Facultad de Ciencias Veterinarias, Universidad de Concepción, Chillán, Chile \\ ${ }^{2}$ Facultad de Ciencias Naturales y Oceanográficas, Universidad de Concepción, Concepción, Chile \\ ${ }^{3}$ Helm West Lab, Missoula, MT, USA \\ ${ }^{4}$ Zoological Institute, Russian Academy of Sciences, Universitetskaya Embankment 1, Saint Petersburg, Russia \\ ${ }^{5}$ Universidad Nacional de Mar del Plata, Mar del Plata, Argentina \\ ${ }^{6}$ Escuela de Medicina Veterinaria, Universidad Santo Tomás, Concepción, Chile
}

Received January 17, 2017

Accepted March 6, 2017

\begin{abstract}
A total of 97 southern silvery grebes (Podiceps occipitalis), which died as the result of an oil spill on the coast of central Chile, were examined for ecto- and endoparasites. Two lice species including Aquanirmus rollandii (Philopteridae) and Pseudomenopon dolium (Menoponidae) were found from 6.2\% (6/97) of birds. In 91.7\% (89/97) of cases, grebes were infected with some kind of helminths. Three species of gastrointestinal helminths were detected: Eucoleus contortus (Nematoda), Profilicollis bullocki (Acanthocephala), and Confluaria sp. (Cestoda). In addition, Pelecitus fulicaeatrae (Nematoda) was removed from the tibiotarsal-tarsometatarsal articulation in $13.4 \%$ (13/97) of the specimens examined. To our knowledge, these are the first records of $A$. rollandii, E. contortus, and Confluaria sp. as parasites of $P$. occipitalis. In addition, these findings expand the distributional range of $A$. rollandii, E. contortus, P. fulicaeatrae, and Confluaria sp. to Chile.
\end{abstract}

Keywords: Acanthocephalans, cestode, nematode, ectoparasites, endoparasites, water birds.

\section{Resumo}

Um total de 97 mergulhōes-de-orelha-amarela (Podiceps occipitalis), que morreram devido a um derramamento de óleo na costa do Chile central, foram examinados em busca de parasitos internos e externos. Parasitos externos foram encontrados em 6,2\% (6/97) das aves, com a identificação de duas espécies de piolhos: Aquanirmus rollandii (Philopteridae) e Pseudomenopon dolium (Menoponidae). Em 91,7\% (89/97) dos casos, os mergulhōes apresentaram algum tipo de parasito interno. Foram detectadas três espécies de parasitos gastrointestinais: Eucoleus contortus (Nematoda), Profilicollis bullocki (Acanthocephala) e Confluaria sp. (Cestoda). Além disso, Pelecitus fulicaeatrae (Nematoda) foi isolado das articulação tibiotársica e tarsometatarsal em 13,4\% (13/97) das aves examinados. Estes resultados correspondem ao primeiro relato de A. rollandii, E. contortus e Confluaria sp. associados com P. occipitalis, e expandem a distribuição destes parasitos e P. fulicaeatrae para o Chile.

Palavras-chave: Acantocéfala, cestoda, nematoides, parasitos externo, parasitos interno, aves aquáticas.

*Corresponding author: Lucila Moreno Salas. Facultad de Ciencias Naturales 


\section{Introduction}

The southern silvery grebe Podiceps occipitalis Garnot, 1826 is widely distributed across South American countries, as it can be found in Argentina (including in the Falkland Islands/Malvinas), Bolivia, Peru, Paraguay, and Chile, although they rarely occur in Ecuador and Colombia (COUVE \& VIDAL, 2003; MAILLARD et al., 2006). In Chile, grebes are represented by two subspecies, $P$. occipitalis occipitalis, which distributed from Atacama to Tierra del Fuego, and P. occipitalis juninensis, which inhabits lakes at higher altitudes $(3500-4500 \mathrm{~m})$ in the Andean plateau (JARAMILLO, 2005). In terms of its conservation status, this species has been categorized as of least concern (LC); however, the overall population appears to be decreasing overall (BIRDLIFE INTERNATIONAL, 2016). Furthermore, $P$. occipitalis is vulnerable to oil spill events due to their gregarious behavior during the winter, as they gather in large water bodies, sea bays, and lagoons to form flocks consisting of hundreds of individuals (JARAMILLO, 2005). Knowledge about parasite diversity and prevalence in $P$. occipitalis is quite limited (HINOJOSA-SÁEZ \& GONZÁLEZ-ACUÑA, 2005; ATKINSON et al., 2008). To date, only a louse, Pseudomenopon dolium Rudow, 1896 (Phthiraptera: Menopodidae), and helminths, Pelecitus fulicaeatrae Diesing, 1861 (Nematoda: Filarioidea) and Profilicollis bullocki Perry, 1942 (Acanthocephala: Polymorphidae), have been described for $P$. occipitalis in Bolivia, Argentina, and Chile, respectively (PRICE et al., 2003; RIQUELME et al., 2006; ESCUDERO et al., 2007). The present study provides new data on the diversity and prevalence of ecto- and endoparasites in the southern silvery grebe that inhabits the coast of central Chile.

\section{Materials and Methods}

In May 2007, an oil spill event occurred along the coast of central Chile, near Lenga Town (36 46’ S, $73^{\circ} 10^{\prime} \mathrm{W}$ ). In order to protect local wildlife, different seabird species were captured and transported to the Wildlife Rehabilitation Center from the Universidad de Concepción, Chillán, so they could be rehabilitated. Unfortunately, 97 grebes (P. occipitalis occipitalis) died while being washed with detergent in order to remove the oil from their feathers. Their carcasses were moved to the Animal Science Department at the Universidad de Concepción and each bird was kept individually frozen at $-12{ }^{\circ} \mathrm{C}$ for further analysis.

The grebes were externally inspected and their feathers were closely examined for ectoparasites. Following collection, the ectoparasites were preserved in $70 \%$ ethanol. Lice were mounted using Canada balsam following the technique of Price et al. (2003); they were identified under a light microscope based on the keys and descriptions of Castro \& Cicchino (2000) and Price et al. (2003). Specimens were photographed via microscope and measured using Micrometrics ${ }^{\circledR}$ (Micrometrics Instrument Corporation, Norcross, GA, USA).

For endoparasites, the carcasses were necropsied using the protocols detailed in Kinsella \& Forrester (1972). Endoparasites were identified following the descriptions provided by Betlejewska et al. (2002), Escudero et al. (2007), Vasileva et al. (1999a, b, 2000, 2001), and Mateo et al. (1982).

\section{Results and Discussion}

Lice including Aquanirmus rollandii Castro \& Cicchino, 2000 (Phthiraptera, Ischnocera) (Figure 1A) (2 females, 1 male, and 2 nymphs) and Pseudomenopon dolium (Figure 1B) (5 females and 2 males) were found on 6.2\% (6/97) of grebes (Table 1). Both parasite species were restricted to Podicipedidae. With respect to A. rollandii, it was only previously reported in Rollandia rolland chilensis (Lesson) in Argentina (CASTRO \& CICCHINO, 2000). In contrast, $P$. dolium is a cosmopolitan species that parasitizes Podiceps ruficollis, P. auritus, P. grisegena, P. cristatus, P. nigricollis, Podilymbus podiceps, Aechmophorus occidentalis, and Tachybaptus ruficollis in Europe, Africa, India, Asia and North America (PRICE, 1974; MARTÍN MATEO, 2006; VAS et al., 2012; DIK \& HALAJIAN, 2013; GALLOWAY et al., 2014; JAŁOSZYŃSKI et al., 2014). In South America, $P$. dolium has been described as a parasite of P. podiceps in Argentina, $R$. rolland chilensis in Chile and Argentina, P. taczanowskii in Peru, and P. occipitalis in Bolivia (PRICE, 1974; CICCHINO, 2011).

Only a small number of individuals from both species were collected. This could be explained by the fact that grebes were covered in oil and subsequently washed with detergent to remove it. For this reason, our study may be underestimating the intensity of infection in the examined birds. Nonetheless, this marks the first time that $A$. rollandii has been identified from $P$. occipitalis, and where its distributional range has expanded to Chile.

For the same reason, feather mites (Acari: Analgoidea and Pterolichoidea), the most abundant and diverse arthropods living on the plumage and bodies of birds, were not detected on the examined carcasses of $P$. occipitalis. Nevertheless, while taking into account the currently known data on feather mites associated with Podicipedidae, it is probable that representatives of at least three different feather mite families (Ptiloxenidae, Xolalgidae and Laminosioptidae) will be found on the southern silvery grebe in Chile. Thus, feather mites of the genus Ptiloxenus Hull, 1934 (Pterolichoidea: Ptiloxenidae) was associated with grebes of the genera Podiceps and Rollandia (DABERT \& EHRNSBERGER, 1998). Ingrassia colymbi Gaud, 1974 (Analgoidea: Xolalgidae), the only
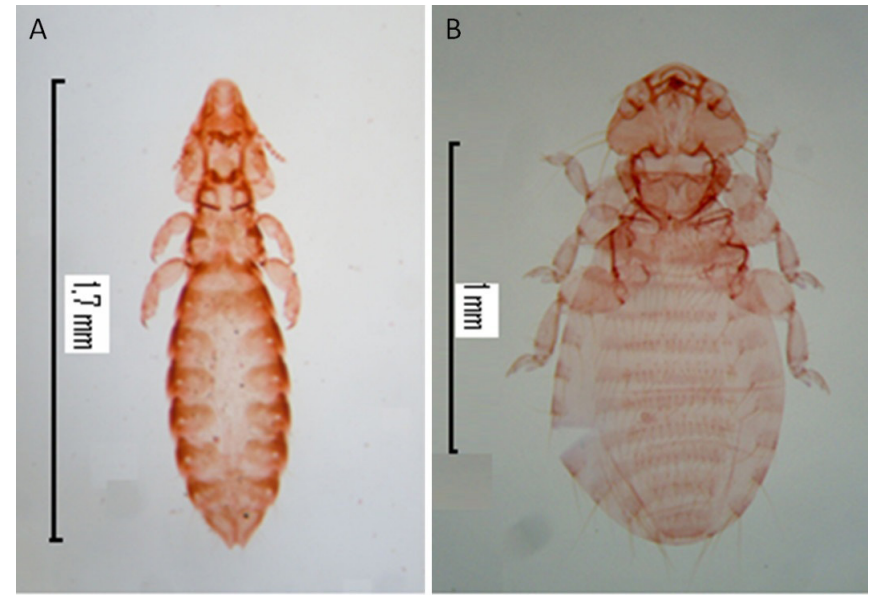

Figure 1. Aquanirmus rollandii female (A) and Pseudomenopon dolium female (B) (100× magnification). 
Table 1. Summary of ecto- and endoparasites identified on the southern silvery grebe Podiceps occipitalis from Central Chile.

\begin{tabular}{lccccc}
\hline \multicolumn{1}{c}{ Parasite } & Location & $\begin{array}{c}\text { Prevalence } \\
(\%)\end{array}$ & $\begin{array}{c}\text { Total } \\
\text { parasites }\end{array}$ & $\begin{array}{c}\text { Range } \\
\text { Intensity }\end{array} \begin{array}{c}\text { Mean } \\
\text { Abundance }\end{array}$ \\
\hline Endoparasites & & & & & \\
Eucoleus contortus & Small intestine & 1.03 & 1 & 1 & 1 \\
Confluaria sp. & Small intestine & 46.39 & 708 & $1-141$ & 15.7 \\
Profilicollis bullocki & Small intestine & 68.04 & 975 & $1-81$ & 14.7 \\
Pelecitus fulicaeatrae & Tibiotarsal-tarsometatarsal articulation & 13.40 & 72 & $1-18$ & 5.01 \\
Ectoparasites & & & & & \\
Aquanirmus rollandii & Feathers & 3.09 & 5 & $1-30.05$ & 0.70 \\
Pseudomenopon dolium & Feathers & 3.09 & 7 & $1-3$ & 0.05 \\
\hline
\end{tabular}

representative of the family associated with grebes, was described from the covert feathers of the bodies of Tachybaptus ruficollis (GAUD, 1974). A quill-wall mite known as Podicipedicoptes americanus (LOMBERT et al., 1979) (Analgoidea: Laminosioptidae), the only representative of the genus Podicipedicoptes, was described from Podilymbus podiceps (LOMBERT et al., 1979). Species of the genus Podicipedicoptes, Ptiloxenus and Ingrassia were also expected to be found on the southern silvery grebe.

Gastrointestinal helminths were found from $91.7 \%$ of southern silvery grebe. In addition, Pelecitus fulicaeatrae (Figure 2) was removed from the tibiotarsal-tarsometatarsal articulation in a smaller number of birds (13.4\% of cases) (Table 1). A female of Eucoleus contortus (syn. Capillaria contorta) was collected from the small intestine of a single grebe. This parasite is normally found in the upper digestive tracts of birds (BETLEJEWSKA et al., 2002) and, in some cases, in the proventriculus (MONTEIRO et al., 2011). It commonly affects domestic Galliformes, but it also parasitizes captive-raised wild birds (MILLÁN et al., 2002; CRUZ et al., 2016). For instance, E. contortus has been described in swans, ducks, gulls, bustards, and cormorants in Asia, Europe and South America (Brazil) (THRELFALL, 1982; FEDYNICH et al., 1997; BOSCH et al., 2000; BETLEJEWSKA et al., 2002; VILLANÚA et al., 2007; YOSHINO et al., 2009; MONTEIRO et al., 2011; SANTORO et al., 2011). This study is the first report of E. contortus from grebes (Podicipedidae), and it expands the parasite's distributional range to Chile. E. contortus is a generalist parasite and it has been reported to parasitize other seabirds. For this reason, it is likely that P. occipitalis plays a role as a natural host for E. contortus. However, it could also represent an accidental infectious event, as only a single E. contortus individual was collected from the 97 grebes examined. The feeding behavior of these birds (mostly insects and aquatic crustaceans) (ROTTMANN, 1995) strengthens the hypothesis for an accidental finding of $E$. contortus, which probably was ingested by this grebe within an invertebrate host. Additionally, one must consider that $P$. occipitalis coexists with different seabirds along the coast of central Chile, including birds that were previously indicated as hosts for E. contortus (e.g. Phalacrocorax brasilianus) (MONTEIRO et al., 2011). Furthermore, this parasite was identified as a possible threat for the conservation of wild species (VILLANÚA et al., 2007), mostly due to its negative effects on the body's overall condition (BOSCH et al., 2000) and its susceptibility to predation (MILLÁN et al., 2002). For these reasons, further studies assessing parasite prevalence and diversity

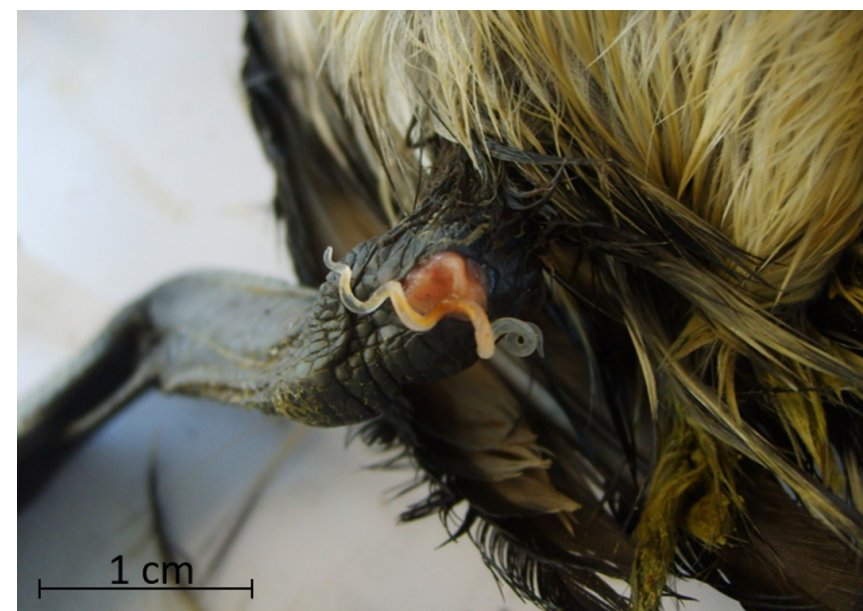

Figure 2. Pelecitus fulicaeatrae removed fron tibiotarsal-tarsometatarsal articulation.

should be performed in Podicipedidae to adequately elucidate their parasite fauna.

Confluaria sp. Ablasov, 1953 (Cestoda: Hymenolepididae) were collected from the small and large intestines of grebes; the latter location is unusual for these parasites, and it may be the result of parasite movements following death. Vasileva et al. (1999a) indicate that the genus Confluaria is restricted to Podicipedidae, and that records in other avian families are erroneous. This genus has been reported in P. ruficollis japonicus, P. nigricollis, Tachybaptus ruficollis, $P$. grisegena, $P$. cristatus and $P$. auritus in Asia and Europe (VASILEVA et al., 1999a, b; BARUŠ et al., 2000; VASILEVA et al., 2000, 2001, 2008; HAUKISALMI, 2015; SITKO \& HENEBERG, 2015). In South America, the genus Confluaria is only known to be from Northern Brazil, with $P$. dominicus serving as its host (VASILEVA et al., 1999a). Therefore, this is the first time that the Confluaria sp. is reported from $P$. occipitalis, thus extending its range to Chile.

In this study, specimens of Profilicollis bullocki, which were aligned with the characteristics of this parasite found in seabirds inhabiting the coast of Central and Northern Chile (OLIVA et al., 1992; RIQUELME et al., 2006), were reported to be highly prevalent in P. occipitalis (68.0\%). Indeed, Riquelme et al. (2006) suggest that $P$. occipitalis may act as a natural reservoir for $P$. bullocki during the winter, thus playing a role in the maintenance of infections in seabird communities during that season. This parasite was previously 
identified in various charadriiform birds, including Calidris sp., Larus modestus, L. serranus, L. dominicanus, L. pipixcan, and Numenius phaeopus, as well as in P. occipitalis on the Pacific Coast of South America (OLIVA et al., 1992; RIQUELME et al., 2006).

In addition, Pelecitus fulicaeatrae was detected in 13 grebes, which were located in the tibiotarsal-tarsometatarsal articulation. Chewing lice such as $P$. dolium act as intermediate hosts (BARTLETT \& ANDERSON, 1987). In the definitive host, microfilariae inhabit the feathered skin of their hosts, and adults occur in the nodules in their legs (BARTLETT \& ANDERSON, 1989). Different bird families have been reported as hosts of $P$. fulicaeatrae, including grebes (VANDERBURGH et al., 1984; BARTLETT \& GREINER, 1986; BARTLETT \& ANDERSON, 1989; ESCUDERO et al., 2007). In South America, the occurrence of $P$. fulicaeatrae was previously reported in the gray-necked wood-rail Aramides cajanea (Rallidae) and in the jabiru Jabiru mycteria (Ciconiidae) in Brazil (PINTO \& NORONHA, 2003). Escudero et al. (2007) reported the first record of $P$. occipitalis from Argentina. Our findings represent a new record of this parasite in Chile.

Our study contributes to the current knowledge on the parasite prevalence and diversity in $P$. occipitalis, which includes the first records of $A$. rollandii, E. contortus, and Confluaria sp. for this host. In addition, it expands the distributional range for $A$. rollandii, E. contortus, P. fulicaeatrae, and Confluaria sp. to Chile.

\section{Acknowledgements}

We appreciate the support given by the National Forest Corporation, CONAF, as well as by the Agricultural and Livestock Service, SAG, of Chile. We thank Karen Ardiles, Carolina Silva, Pedro Álvarez, Sebastián Muñoz, Braulio Muñoz, Danny Fuentes, Félix Varas, Ignacia Najle, Iván Torres, Nicolás Fernández, Pablo Olmedo, and Diego Barrientos for their support in the field. This research was funded by FONDECYT Project 1130948.

\section{References}

Atkinson CT, Thomas NJ, Hunter DB. Parasitic diseases of wild birds. Ames: Willey-Blackwell; 2008. http://dx.doi.org/10.1002/9780813804620.

Bartlett CM, Anderson RC. Mallophagan vectors and the avian filarioids: new subspecies of Pelecitus fulicaeatrae (Nematoda: Filarioidea) in sympatric North American hosts, with development, epizootiology, and pathogenesis of the parasite in Fulica americana (Aves). Can J Zool 1989; 67(11): 2821-2833. http://dx.doi.org/10.1139/z89-398.

Bartlett CM, Anderson RC. Pelecitus fulicaeatrae (Nematoda: Filarioidea) of coots (Gruiformes) and grebes (Podicipediformes): skin-inhabiting microfilariae and development in Mallophaga. Can J Zool 1987; 65(11): 2803-2812. http://dx.doi.org/10.1139/z87-423.

Bartlett CM, Greiner EC. A revision of Pelecitus Railliet \& Henry, 1910 (Filarioidea, Dirofilariinae) and evidence for the "capture" by mammals of filarioids from birds. Bull Mus Hist Nat 1986; 8(1): 47-99.

Baruš V, Tenora F, Kráčmar S. Heavy metal ( $\mathrm{Pb}, \mathrm{Cd}$ ) concentrations in adult tapeworms (Cestoda) parasitizing birds (Aves). Helminthologia 2000; 37(3): 131-136.
Betlejewska KM, Kalisinska E, Kornyushin VV, Salamatin R. Eucoleus contortus (Creplin, 1839) nematode in mallard (Anas platyrhynchos Linnaeus, 1758) from north-western Poland. Electron J Polish Agric Univ 2002; 5(1): 3.

BirdLife International. Species factsheet: Podiceps occipitalis. Cambridge: BirdLife International; 2016 [cited 2016 June 28]. Available from: http:// www.birdlife.org/datazone/species/factsheet/62114375

Bosch M, Torres J, Figuerola J. A helminth community in breeding Yellow-legged Gulls (Larus cachinnans): pattern of association and its effect on host fitness. Can J Zool 2000; 78(5): 777-786. http://dx.doi. org/10.1139/cjz-78-5-777.

Castro D, Cicchino A. A new species of Aquanirmus Clay and Meinertzhagen, 1939 (Phtriraptera, Philopteridae) parasitic on Rollandia Rolland chilensis (Lesson, 1828) (Aves, Podicipitidae), with remarks on the external chorionic morphology of the eggs. Pap Avulsos Zool 2000; 41(14): 213-221.

Cicchino AC. Piojos (Insecta: Psocodea: Phthiraptera) parásitos de Gruiformes y Podicipediformes (Aves) en la Argentina [Dissertation]. Mar del Plata: Universidad Nacional de Mar del Plata; 2011.

Couve E, Vidal C. Birds of Patagonia, Tierra Del Fuego and Antarctic Peninsula: the Falkland Islands and South Georgia. Punta Arenas: Fantástico Sur Birding; 2003.

Cruz CEF, Fredo G, Casagrande R, Oliveira L, Rolim V, Marques S, et al. Eucoleus contortus parasitism in captive-bred valley quail Callipepla californica (Shaw, 1798): disease and control. Zool Gart 2016; 85(3-4): 152-159. http://dx.doi.org/10.1016/j.zoolgart.2016.01.008.

Dabert J, Ehrnsberger R. Phylogeny of the feather mite family Ptiloxenidae Gaud, 1982 (Acari: Pterolichoidea). In: Ebermann E. Arthropod biology: contributions to morphology, ecology and systematics. 1998. p. 145-178. vol. 14. Biosystematics and Ecology Series.

Dik B, Halajian A. Chewing lice (Phthiraptera) of several species of wild birds in Iran, with new records. J Arthropod Borne Dis 2013; 7(1): 83-89. PMid:23785698.

Escudero G, Diaz JI, Notarnicola J. New host and distribution records of Pelecitus fulicaeatrae (Diesing, 1861) (Nematoda, Onchocercidae). Acta Parasitol 2007; 52(4): 419-421. http://dx.doi.org/10.2478/s11686007-0058-4.

Fedynich AM, Pence DB, Bergan JF. Helminth community structure and pattern in sympatric populations of double-crested and Neotropic cormorants. J Helminthol Soc Wash 1997; 64(2): 176-182.

Galloway TD, Proctor HC, Mironov SV. Chewing Lice (Insecta: Phthiraptera: Amblycera, Ischnocera) and Feather Mites (Acari: Astigmatina: Analgoidea, Pterolichoidea): Ectosymbionts of Grassland Birds in Canada. In: Cárcamo HA, Giberson DJ. Arthropods of Canadian Grasslands: Biodiversity and Systematics (volume 3) Part 1. Ottawa: Biological Survey of Canada; 2014. p. 139-188.

Gaud J. Quelques espèces nouvelles de Sarcoptiformes plumicoles (Analgidae \& Dermoglyphidae) parasites d'oiseaux d'Europe. Acarologia 1974; 15(4): 727-758. PMid:4446922.

Haukisalmi V. Checklist of tapeworms (Platyhelminthes, Cestoda) of vertebrates in Finland. ZooKeys 2015; 533(533): 1-61. PMid:26668540. http://dx.doi.org/10.3897/zookeys.533.6538.

Hinojosa-Sáez A, González-Acuña D. Estado actual del conocimiento de helmintos en aves silvestres de Chile. Gayana (Concepc) 2005; 69(2): 241-253. 
Jałoszyński P, Gustafsson DR, Wanat A, Wanat M. Type specimens of Phthiraptera in the collection of Jadwiga Złotorzycka preserved in the Museum of Natural History, University of Wrocław. Genus 2014; 25(4): 645-661.

Jaramillo A. Aves de Chile. Barcelona: Lynx Edicions; 2005.

Kinsella JM, Forrester DJ. Helminths of the Florida duck, Anas platyrhynchos fulvigula. Proc Helminthol Soc Wash 1972; 39(2): 173-176.

Lombert HAPM, Kethley JB, Lukoschus FS. Observations on quill wall mites from American birds (Acaridei: Laminosioptidae: Faincoptinae). Int J Acarol 1979; 5(2): 103-110. http://dx.doi.org/10.1080/01647957908683132.

Maillard O, Sánchez G, Caballero E, Velásquez MÁ. Nuevo dato en la distribución de Podiceps occipitalis en Bolivia. Kempfiana 2006; 2(1): 106-108.

Martín Mateo MP. Diversidad y distribución de las especies de Mallophaga (Insecta) en aves y mamíferos de la comunidad de Madrid. Graellsia 2006; 62: 21-32. http://dx.doi.org/10.3989/graellsia.2006.v62.iExtra.108.

Mateo E, Córdova R, Guzmán E. Polymorphus (Profilicollis) bullocki, nueva especie de acantocéfalo hallado en la gaviota Larus belcheri en el Perú. Bol Lima 1982; 4(24): 73-78.

Millán J, Gortázar C, Tizzani P, Buenestado FJ. Do helminths increase the vulnerability of released pheasants to fox predation? J Helminthol 2002; 76(3): 225-229. PMid:12363375. http://dx.doi.org/10.1079/ JOH2002125.

Monteiro CM, Amato JF, Amato SB. Helminth parasitism in the Neotropical cormorant, Phalacrocorax brasilianus, in southern Brazil: effect of host size, weight, sex, and maturity state. Parasitol Res 2011; 109(3): 849855. PMid:21431903. http://dx.doi.org/10.1007/s00436-011-2311-x.

Oliva ME, Luque JL, Cevallos A. Parásitos de Emerita analoga (Stimpson) (Crustacea): implicancias ecológicas. Bol Lima 1992; 79: 77-80.

Pinto RM, Noronha D. Analysis of Brazilian species of Pelecitus Railliet \& Henry (Nematoda, Filarioidea) with the establishment of new records. Rev Bras Zool 2003; 20(2): 361-364. http://dx.doi.org/10.1590/S010181752003000200029 .

Price RD, Hellenthal RA, Palma RL, Jonhson KP, Clayton DH. The chewing lice: world checklist and biological overview. Springfield: Illinois Natural History Survey; 2003.

Price RD. A review of the genus Pseudomenopon (Mallophaga: Menoponidae). Ann Entomol Soc Am 1974; 67(1): 73-84. http://dx.doi.org/10.1093/ aesa/67.1.73.

Riquelme C, George-Nascimento M, Balboa L. Morfometría y fecundidad de Profilicollis bullocki Mateo, Córdova \& Guzmán 1982 (Acantocephala: Polymorphidae) en especies simpátricas de aves costeras de Chile. Rev Chil Hist Nat 2006; 79(4): 465-474. http://dx.doi.org/10.4067/S0716078X2006000400005.

Rottmann J. Guia de identificación de aves de ambientes acuáticos. Chile: Unión de Ornitólogos de Chile; 1995.
Santoro M, Mattiucci S, Kinsella JM, Aznar FJ, Giordano D, Castagna F, et al. Helminth community structure of the Mediterranean gull (Ichthyaetus melanocephalus) in Southern Italy. J Parasitol 2011; 97(2): 364-366. PMid:21506790. http://dx.doi.org/10.1645/GE-2602.1.

Sitko J, Heneberg P. Host specificity and seasonality of helminth component communities in central European grebes (Podicipediformes) and loons (Gaviiformes). Parasitol Int 2015; 64(5): 377-388. PMid:26008120. http://dx.doi.org/10.1016/j.parint.2015.05.012.

Threlfall W. Endoparasites of the double-crested cormorant (Phalacrocorax auritus) in Florida. Proc Helminthol Soc Wash 1982; 49(1): 103-108.

Vanderburgh DJ, Anderson RC, Stock TM. Pelecitus tubercauda n. sp. (Nematode: Filarioidea) from Geothlypis trichas L. and a redescription of P. fulicaeatrae (Diesing, 1861) López-Neyra, 1956. Can J Zool 1984; 62(3): 362-367. http://dx.doi.org/10.1139/z84-056.

Vas Z, Rékási J, Rózsa L. A checklist of lice of Hungary (Insecta: Phthiraptera). Annls Hist Nat Mus Natn Hung 2012; 104: 5-109.

Vasileva GP, Georgiev BB, Genov T. Palaearctic species of the genus Confluaria Ablasov (Cestoda, Hymenolepididae): a redescription and synonymy of $C$. capillaris (Rudolphi, 1810). Syst Parasitol 1999a; 43(1): 49-57. PMid:10613530. http://dx.doi.org/10.1023/A:1006132708859.

Vasileva GP, Georgiev BB, Genov T. Palaearctic species of the genus Confluaria Ablasov (Cestoda, Hymenolepididae): redescriptions of C. multistriata (Rudolphi, 1810) and C. japonica (Yamaguti, 1935), and a description of Confluaria sp. Syst Parasitol 1999b; 44(2): 87-103. PMid:10619078. http://dx.doi.org/10.1023/A:1006157504152.

Vasileva GP, Georgiev BB, Genov T. Palaearctic species of the genus Confluaria Ablasov (Cestoda, Hymenolepididae): redescriptions of C. podicipina (Szymanski, 1905) and C. furcifera (Krabbe, 1869), description of $C$. pseudofurcifera n. sp., a key and final comments. Syst Parasitol 2000; 45(2): 109-130. PMid:10743855. http://dx.doi. org/10.1023/A:1006237509781.

Vasileva GP, Kornyushin VV, Genov T. Hymenolepidid cestodes from grebes (Aves, Podicipedidae) in Ukraine: the genus Confluaria. Vest Zool 2001; 35(6): 13-31.

Vasileva GP, Skirnisson K, Georgiev BB. Cestodes of the horned grebe Podiceps auritus (L.) (Aves: Podicipedidae) from Lake Myvatn, Iceland, with the description of Confluaria islandica n. sp. (Hymenolepididae). Syst Parasitol 2008; 69(1): 51-58. PMid:18030602. http://dx.doi. org/10.1007/s11230-007-9110-x.

Villanúa D, Casas F, Viñuela J, Gortázar C, De la Morena EG, Morales M. First occurrence of Eucoleus contortus in a Little Bustard Tetrax tetrax: negative effect of Red-legged Partridge Alectoris rufa releases on steppe bird conservation? Ibis 2007; 149(2): 405-406. http://dx.doi. org/10.1111/j.1474-919X.2006.00620.x.

Yoshino T, Uemura J, Endoh E, Kaneko M, Osa Y, Asakawa M. Parasitic nematodes of anseriform birds in Hokkaido, Japan. Helminthologia 2009; 46(2): 117-122. http://dx.doi.org/10.2478/s11687-009-0023-x. 